\title{
Do LGBT workplace diversity policies create value for firms?
}

\begin{abstract}
We show that U.S. anti-discriminatory laws prohibiting discrimination in the workplace based on sexual orientation and gender identity (i.e. lesbian, gay, bisexual, and transgender (LGBT) identities) spur innovation, which ultimately leads to higher firm performance. We use the Human Rights Campaign's Corporate Equality Index (CEI) of 398 (1,592 firm-year observations) U.S. firms between 2011 and 2014, and find a significantly positive relationship between CEI and firm innovation. We also find that an interacting effect of CEI and firm innovation leads to higher firm performance. We use our understanding of Rawls' Theory of Justice and stakeholder theory to show that firms with workplace diversity policies are likely to be more innovative and perform better than those without such policies. Our results are robust to endogeneity, reverse causality and simultaneity issues. Our results will trigger debate in similar markets around the globe on the economic benefits of LGBT workplace diversity policies for firms.
\end{abstract}

Keywords: Workplace diversity, LGBT, Innovation, Firm performance 


\section{Introduction}

Support for LGBT (lesbian, gay, bisexual, and transgender, hereafter LGBT) rights has increased substantially over the last two decades in Australia, UK, USA, and other European countries (Lloren \& Parini, 2017; Pichler, Blazovich, Cook, Huston, \& Strawser, 2018). Consequently, corporate equality initiatives, and more specifically, employee equality initiatives are becoming an integral part of firms' diversity management. These initiatives signal an open and tolerant workplace environment in which employees are not discriminated against on the basis of their sexual orientation or gender identity. ${ }^{1}$ Liddle, Luzzo, Hauenstein, \& Schuck (2004) emphasize that workplace environment plays a key role in employee recruitment, productivity, stress and commitment. It is estimated that approximately eight million people, or 3.5\% of the U.S population, identify as LGBT (Gates, 2011, 2012) and 30 states have no laws protecting the employment rights of LGBT individuals (Webster, Adams, Maranto, Sawyer, \& Thoroughgood, 2018). Research has shown that individuals who identify as LGBT face discrimination, hostility and negative attitudes (homophobia and transphobia) in the workplace, which negatively affects their performance on the job in terms of higher absenteeism and lower productivity (Bonaventura \& Biondo, 2016).

To improve the workplace environment, in 2017, the U.N. High Commissioner for human rights released new standards of conduct to eliminate discrimination against LGBT employees in the workplace. ${ }^{2}$ These anti-discriminatory policies have both societal and economic benefits. For example, formal acceptance of LGBT employees in the workplace makes them feel less anxious, less threatened, and more comfortable (Liddle et al., 2004). In terms of economic benefits, in Australia, it has been estimated that acceptance of secluded

\footnotetext{
1 The extant literature from various fields, including history, sociology, and psychology, concurs that discrimination against LGBT groups exists because of both sexual orientation and gender identity (e.g. Badgett, 1995; Drydakis, 2009; King \& Cortina, 2010; Ozeren, 2014; Bonaventura \& Biondo, 2016).

2 These standards include respect, elimination and prevention of discrimination, support, and taking a stand for LGBT individuals.
} 
workers in different workplaces could lead to as much as \$285 million in savings per year nationally, an increase of $11 \%$ in staff retention and $30 \%$ in productivity (Johnson \& Cooper, 2015). At the organizational level, acceptance of LGBT groups increases the pool of talent from which organizations may draw strategic benefits, and such inclusion leads to an increase in diversity in different positions and professional teams within the organization (Barbulescu \& Bidwell, 2013). However, although promoters of LGBT supportive policies argue that these enhance the talent pool and improve firm level diversity, very little attention has been paid to whether these policies create value for firms.

To recognise the economic effects of LGBT workplace policies, this paper focuses on the effect of LGBT workplace policies ${ }^{3}$ in value creation for firms. A growing number of studies have focused on the social imperative of workplace policies, i.e., discrimination and LGBT workplace policies (Ragins \& Cornwell, 2001; Priola, Lasio, De Simone, \& Serri, 2014), diversity and LGBT workplace policies (Ozturk \& Tatli, 2016), stigma in the workplace and LGBT workplace policies (Ragins, 2008), and politics and LGBT workplace policies (Gupta, Briscoe \& Hambrick, 2017; Rhodes, 2017). However, only a limited number of studies have focused on the economic imperative of workplace policies, i.e., firm performance and LGBT workplace policies (Shan \& Zheng, 2017; Pichler et al., 2017, 2018). In this paper, we seek to investigate the impact of LGBT workplace policies on firms' innovation, and ultimately on firm performance.

We use Rawls' Theory of Justice (1971) to explain ethical corporate behaviour, social responsibility, societal fairness and equality (Chapman, 1975). This theory points to fairness as a social good and suggests that institutions (in this case, firms) have a responsibility and an

\footnotetext{
${ }^{3}$ LGBT workplace policy is measured through the Corporate Equality Index (CEI), which is published annually by Human Rights Campaign (HRC), the largest organisation for LGBT rights in the U.S. This index rates the firms from 0 to 100 points with 100 as highest score based on different sub-policies (e.g. sexual orientation nondiscrimination policies, domestic partner benefits policies, workplace training and LGBT supportive policy guidelines).
} 
opportunity to demonstrate how to treat others (in this case, employees) fairly. The theory further specifies that fairness should not be contingent upon socio-demographic characteristics. Instead, fairness at the workplace should be rooted within a workers' meritocracy. Prior literature that has confirmed Rawls' (1971) concept of fairness and its value to organizational outcomes is limited to some specific socio-demographic factors, i.e. race and religion (Beckley 1986; Cohen, 2010). To date, no research on Rawls' (1971) contribution is extended specifically to the fairness of LGBT employees in the workplace. We apply the Theory of Justice to the challenges faced by the LGBT community, and show how transparent corporate communication that reflects fairness, i.e., LGBT supportive workplace policies, may have implications for organizational outcomes. Moreover, we use stakeholder theory, which builds on the premise that all firms' stakeholders should be treated fairly and equally (Fieseler, Fleck, \& Meckel, 2010), to demonstrate that firms, through transparent corporate communication, create value for stakeholders, which ultimately adds value to the firm.

To empirically answer our research question, we use data from the Human Rights Campaign (HRC) that provide information on firms' overall Corporate Equality Index (CEI) score, sexual orientation non-discrimination policies, gender identity non-discrimination policies, domestic partner benefits, and transgender policies from 2011-2014. We find a significant positive relationship between the CEI score and individual policies with firms' levels of innovation, which ultimately positively affect firm performance.

Our study may face critique on potential endogeneity bias due to the causal effect of CEI on innovation. For instance, a manager who is sensitive to the benevolent effects of corporate social equality may hire more LGBT employees by implementing LGBT supportive workplace policies that will ultimately improve firm innovation. On the other hand, firms keen on innovation may also be responsive to external and societal expectation in terms of implementing LGBT workplace policies. We employ two techniques to minimize these 
endogeneity concerns: propensity score matching and dynamic panel estimation (Generalized Method of Moments (GMM)). Our results are robust to these sensitivity techniques and to alternate proxies of firm innovation.

Our contribution to the existing literature is two-fold. First, we contribute to the literature on Rawls' Theory of Justice (1971) by extending its construct of fairness to LGBT employees and policies in the workplace that create value for organizations. Second, we provide empirical evidence to support our arguments on how LGBT workplace policies positively affect firm outcomes. More specifically, we contribute to the existing literature by investigating the actual driver of value-addition, i.e., firm innovation. Previous studies that found a positive association between LGBT workplace policies and firm performance failed to provide a channel through which these policies may have an impact on firm performance. In this study, we confirm the argument that LGBT workplace policies improve firm performance through innovation. Our study is also timely and supports the upsurge in calls for LGBT rights in workplaces around the globe.

The remainder of the paper is structured as follows. Section 2 discusses the intrarelationship between workplace diversity management policies, accounting and innovation. Section 3 discusses the theory and develops hypothesis. Section 4 presents the research design. Section 5 reports our empirical results and discussion. Section 6 presents our conclusions, including the implications of our findings and the limitations of our research.

\section{Workplace diversity management, accounting and innovation:}

With respect to the workplace, diversity refers to the co-existence of employees from various socio-cultural backgrounds. The equal opportunity philosophy is aimed at ensuring that organizations make the most out of the uniqueness of a diverse workforce, which might assist the organization to be more efficient and effective, rather than losing talent. Broadly, diversity management is the systematic and planned commitment by an organization to recruit, retain, 
reward and promote a heterogeneous mix of employees (Grobler et al., 2006). Nowadays, for many leading businesses, it is a strategic imperative to create a culture of inclusion and diversity that extends to LGBT people: they know that it correlates to greater individual performance and ultimately, stronger business performance. For example, $85 \%$ of Fortune 500 businesses have explicit policies against discrimination based on sexual orientation, and $49 \%$ include gender identity (Kelly, 2016). Prior studies have found that various forms of diversity are associated with greater innovation, improved strategic decision making, and better outcomes when innovation and complex problem-solving are required (Jackson \& Joshi, 2004; Francoeur et al., 2008; Omankhanlen and Ogaga, 2011).

Hopwood (1987) states that 'Accounting is not a static phenomenon' (p. 207). Over time, accounting has been implicated in the creation of very different patterns of organizational segmentation (Hopwood, 1987). If accounting is a machine (Burchell, Clubb, Hopwood, Hughes, \& Nahapiet, 1980), it is a mechanical procedure that offers propositions about problems to be concerned with in the future (Mouritsen \& Kreiner, 2016). Therefore, accounting is relevant in many different situations. When decision making is considered as a rational procedure, accounting is understood as an answering machine calculating the economic consequences of various decision alternatives (Mouritsen \& Kreiner, 2016). If decision making is understood in less rational terms, accounting may play a much more complex role, as a learning, ammunition and rationalization machine (Stambaugh \& Carpenter, 1992; Palincsar, 1998; Mouritsen \& Kreiner, 2016). On the other hand, the accounting information also creates conditions for the possibility of the emergence of a new interpretation of the organization's activities, new criteria for action and managerial structures (Dent 1990; Ezzamel \& Bourn, 1990). Indeed, it is a general belief that greater transparency is a prerequisite for developing more useful accounting information, as well as improved organizational accountability (Roberts, 2009). In this case, our assumption is that corporate accounting 
information is largely embedded within the corporate strategies that are taken by the board of directors in relation to corporate performance and human resource policy that required workplace contextual support for LBGT employees (Webster et al., 2018; Pichler et al., 2018).

It is established that in the case of workplace discrimination, employers limit their available talent pool by discriminating against qualified applicants because of their sexual orientation and/or gender identity (Tilcsik, 2011). Literature concurs that LGBT employees experience less discrimination when their employers have non-discrimination policies that include sexual orientation and gender identity, and are more amenable to the efforts of strategic outcomes and values of the organization (Schneider et al., 2013). Moreover, companies that are more diverse and inclusive are better able to compete, and have higher levels of innovation and creativity. In a global survey of companies with a turnover of more than $\$ 500$ million, $85 \%$ agreed that workforce diversity encourages different perspectives, which drive innovation (Forbes Insights 2011). As diversity in the workplace is related to increased innovation, improved strategic decision making, and greater problem-solving skills within business teams (Jackson \& Joshi, 2004; Francoeur et al., 2008), we can conclude that there is a relationship between workplace diversity management in relation to LGBT employees, accounting and innovation. LGBT-supportive workplace policies can bring about two specific benefits that can have a positive impact on the corporate bottom line (Sears \& Mallory, 2011): retention of talented employees, and new ideas and innovation generated by drawing upon a diverse workforce with a wide range of characteristics.

\section{Theory and hypothesis development}

Rawls' Theory of Justice (1971)

Rawls' (1971) Theory of Justice has received enormous attention from scholars in a wide range of disciplines (Chapman, 1975; Bond \& Park, 1991). This theory offers a rational accommodation of freedom and equality (Chapman, 1975). It also provides a foundation, based 
on the idea of fairness, which links the demands of justice to a more general mode of reasoning (Sen, 1995). The successful integration of the ideas of fairness, rationality, reasonableness, objectivity, and reflective equilibrium show Rawls' theory of justice to be remarkably effective.

The tolerance of gender inequality is closely related to notions of legitimacy and correctness (Sen, 1995). In theory, the State should guarantee the freedom and liberty of all its citizens, human rights, rule of law, participation, fairness and justice (Freeman, 2006; Petersmann, 2008). Firms should provide guarantees on what is essentially described as "equality of opportunity", i.e., that there should be no discrimination (legal or de facto) against any group of people (or minority) based on the values and identity they uphold (De Hart, 1994; Gavrilovic, 2016).

Rawls consistently points out that the organizational institution has the resources and the opportunity to treat others fairly, and to reward employees not according to a specific sociodemographic factor such as race, religion or gender, but according to their merit, based on work competency within the institution (Rawls, 1971). Rawls also adds that because the institution has a unique opportunity to advance fairness and meritocratic values in society at large, a greater ethical imperative is placed upon the institution to do so (Rawls, 1971). The employees who work in a company also have a platform to advance the fairness principle in the workplace.

\section{Stakeholder Theory}

Researchers have long been interested in the process of social change through activist pressure on corporations (Briscoe, Chin, \& Hambrick, 2014) in order to create an environment of equality, sometimes with specific reference to sexual orientation and gender identity policies in the workplace (Pichler et al., 2018). Other researchers investigate corporate disclosures and corporate social responsibility (CSR) practices, which are vehicles of communication between corporations and stakeholders. There are many theoretical perspectives on corporate 
disclosures, many of which are closely tied to stakeholder theory (Donaldson \& Preston, 1995; Pichler et al., 2018).

The key proposition of stakeholder theory is that firms have a variety of stakeholders, who are affected by or affect firms' outcomes (Freeman, 1984). It is important to include and represent the stakeholders and their interests within the firm because it is not only management who contribute to the success of an organization, but also stakeholders, such as customers, suppliers, and employees, who also make important contributions to the organization (Baker \& Anderson, 2010). A limitation of stakeholder theory, as noted by Fieseler et al. (2010), is that it does not include ethical guidelines for communication and treating all stakeholders equally. The existing literature provides a rich discussion on how stakeholders are valued equally (or not) and how their interests are addressed (or not) within the organization (Turnbull, Greenwood, Tworoger, \& Golden, 2011; Van Dijk, van Engen, \& Paauwe, 2012).

The commitment to diversity, equality and inclusiveness towards LGBT groups is an important aspect of CSR (Snider, Hill, \& Martin, 2003; Colgan, 2011). Therefore, our assumption is that LGBT-supportive policies in a firm are increasingly important as part of workplace diversity management, which should be communicated in a transparent way to all stakeholders, for example through the CSR report. Stakeholders seek to shape equitable employment practices through negotiations inside organizations (Bidwell, Briscoe, FernandezMateo, \& Sterling, 2013). Human Rights Campaign (HRC), the largest national LGBT civil rights organization in the USA, collected data based on an annual survey to rate U.S. firms on how they treated LGBT employees, with the compliance of pre-determined questions scoring a maximum of $100 .{ }^{4}$ This suggests that a pressure group like HRC, which is an example of a stakeholder, through its compiled Corporate Equality Index, can create value for other stakeholders, and ultimately for firms. From a stakeholder perspective, if a firm implements

\footnotetext{
${ }^{4}$ A detailed discussion has been included in the research design.
} 
LGBT-supportive workplace policies, it provides a signal to potential employees and the market that the firm is socially responsible in terms of anti-discrimination policies and support for diversity (Theodorakopoulos \& Budhwar, 2015; Pichler et al., 2018).

\section{Hypothesis development}

Innovation is an important determinant of firm-level competitiveness (Porter \& Stern, 2001) and is of interest to many stakeholders (Fang, Tian, \& Tice, 2014). The literature on the business case for diversity builds on the assertion that diversity brings innovation, creativity and problem-solving skills (Østergaard, Timmermans, \& Kristinsson, 2011). Research also indicates that LGBT-supportive workplace policies are increasingly important to employees regardless of their own sexual orientation and gender identity (Badgett et al., 2007; Cordes, 2012). Although prior studies have linked LGBT-supportive workplace policies to a variety of social imperatives and firm outcomes, i.e., firm performance and stock returns, our study investigates the actual existence of value-addition (Hypothesis). In short, we believe that firms, through effective workplace diversity management (i.e., implementation of LGBT workplace policies) can improve their competitiveness in the market. Consistent with prior research on the importance of innovation to stakeholders and the positive effects of LGBT-supportive workplace policies on firm outcomes, we hypothesize:

H: LGBT workplace policies are positively associated with firm innovation.

\section{Research design}

Our data on corporate workplace policies are collected manually from the Human Rights Campaign (HRC) annual reports that provide information on firms' overall Corporate Equality Index (CEI) score, sexual orientation non-discrimination policies, gender identity non-discrimination policies, domestic partner benefits, and transgender policies from 20112014. The HRC survey includes firms from Standard and Poor's 500, Forbes' list of the 200 
largest privately held firms, and the Fortune 500 largest publicly traded firms. ${ }^{5}$ Prior research (e.g., Johnston and Malina, 2008; Wang and Schwarz, 2010, Shan, Fu, \& Zheng, 2017) has used the HRC CEI scores to study the impact of LGBT-supportive corporate policies on firms' outcomes (such as firm performance). We collect firm innovation, accounting and governance characteristics from Bloomberg that reports data on firm patents, trademarks, copyrights, research and development, board size, and leverage among others. Consistent with the previous studies (e.g., Chen, Leung, \& Goergen, 2017), we match both data sets and require sample firm-years to have corporate workplace policies, governance, and accounting data in order to be included as part of the sample. Our final sample consists of 398 firms or 1,592 firm-year observations.

\section{Empirical model and variables}

To examine the impact of CEI on firm innovation, we estimate the following baseline model:

Innovation $_{i, t}=\alpha+\beta_{1}\left(\right.$ Corporate_Equality $_{i, t}+\beta_{2}\left(\right.$ Board_Characteristics $_{i, t}+$

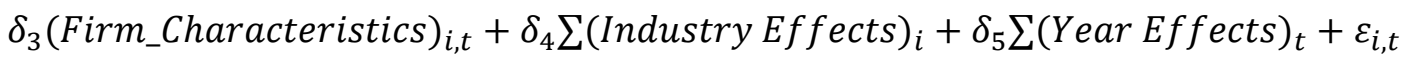

We measure our dependent variable innovation as the number of patents, trademarks, and copyright $(P T C)$ grants in a year. We choose our measurement of innovation based on several factors. First, this measurement shows the true economic value of innovation that has been created and recognized, through grants of patents, trademarks and copyrights in a year (Hall, Jaffe, \& Trajtenberg, 2005). Second, this measurement provides precise assessment of the outcome of a firm's efforts and investment in innovation. Third, our measurement is based on innovation outcome rather than input (e.g., research and development expenditure).

\footnotetext{
${ }^{5}$ In 2002, the HRC (largest national LGBT civil rights organization in the USA) began conducting an annual survey to rate US firms on how they treat their LGBT employees, investors, and consumers. The HRC publishes an annual report on the Corporate Equality Index (CEI).
} 
However, we also employ the input-based measurement of innovation, i.e., research and development expenditures $\left(L n \_R \& D\right)$ following Miller \& Triana (2009). Other alternative measures of innovation include patents, trademarks and copyrights per employee, per sales (PTC/Emp, PTC/Sales), and research and development per sales (R\&D/Sales), respectively.

The variable of interest in this study is workplace diversity policies. The HRC annual reports on the Corporate Equality Index rates a firm on a scale, ranging from 0 to 100, with 100 being the highest equality. ${ }^{6}$ The measure includes not only the workplace diversity policies that the firm has in place, but also the training taking place, involvement with the LGBT community, and responsible citizenship of the firm. The rating criteria include points assigned to a firm according to whether its employment policies include sexual orientation, gender identity and diversity training, supportive gender transition guidelines, domestic partner insurance, and transgender wellness benefits. For example, according to 2014 criteria, a policy such as non-discrimination on sexual orientation earns 15 points, non-discrimination on gender identity earns 15 points, and partner health insurance earns 15 points. The point breakdown for diversity policies is publicly available. The HRC Corporate Equality Index has been commonly used by prior studies to investigate different firm level outcomes (e.g., Wang \& Schwarz, 2010; Cook \& Glass, 2016; Shan et al., 2017). In addition to CEI (the umbrella measure), we also employ a set of dummy variables to measure the individual policies. First, we employ dummy variable $(S O N D P)$ that equals 1 if a firm has a sexual orientation non-discrimination policy in place and 0 otherwise. Second, we use dummy variable (GINDP) that equals 1 if a firm has a gender identity non-discrimination policy in place, and 0 otherwise. Third, we assign dummy variable $(D P B)$ that equals 1 if a firm has a domestic partner benefits policy in place, and 0

\footnotetext{
${ }^{6}$ The HRC asks the largest organizations to submit a survey for this index. However, their compliance is voluntary, and organizations can also submit responses, if not asked by HRC. The HRC CEI measure includes a comprehensive set of sexual equality and gender identity policies and the measure is used by extant literature. However, we acknowledge that it may not be a perfect measure due to the likelihood of certain perceptions and limitations of this organisation (HRC).
} 
otherwise. Finally, we employ dummy variable $(T G)$ that equals 1 if a firm has a transgender benefits policy in place, and 0 otherwise.

We use two types of control variables: corporate governance and firm characteristics. Our selection of control variables is based on prior studies (e.g., Cook \& Glass, 2016; Chen et al., 2017). Chen et al. (2017) show that corporate board characteristics are also important determinants of corporate policies. Therefore, we include a variety of board-specific variables to capture the quality of corporate governance, such as board size (Bsize) (measured as the total number of directors on the board); CEO duality (Duality) serves as proxy for CEO power (a dummy variable that equals 1 if the CEO is a chairman of the board, and 0 otherwise); board independence $($ Bind) is considered an effective monitoring tool (Fama \& Jensen, 1983) to implement societal shifts towards the LGBT community, as board independence is more likely to promote workplace diversity policies (measured as the number of independent directors divided by the board size); and regular board meetings (Ln_bmeeting) which improve the board's monitoring ability (Rutherford \& Buchholtz, 2007) and tend to approve diversity supportive initiatives (measured as the log of the total number of board meetings held in a year).

The firm characteristics include firm-specific variables, such as: size of the firm (Firm size), which is measured as the natural log of total assets; $R O A$, return on assets, which is a measure of financial health; and Leverage, which is measured as total debt (short- and longterm) to total assets. Tobin's $q$, a proxy for growth opportunities, is the ratio of the book value of assets minus the book value of equity plus the market value of equity to the book value of assets. Inside ownership (Insideown), a proxy for internal ownership, is measured as shares held by insiders to total outstanding shares. Capex, a proxy for capital expenditure, is measured by total capital expenditure divided by total assets.

[Insert Table 1 here] 
To test our empirical model, we use ordinary least square (OLS) as the baseline method and include industry (based on two-digit codes of GICS industry sectors) and year effects. The standard errors are corrected for through the clustering of residuals at the firm level to control for heteroscedasticity and within-firm correlation in the residuals (Petersen, 2009). ${ }^{7}$ We also specify one-year lagged independent variables by replacing the contemporaneous variables in the regressions to mitigate the endogeneity concerns (Harford et al., 2008). The underlying rationale is that diversity policies and board characteristics require time to influence firm innovation.

\section{Descriptive statistics}

Table 2 presents the summary statistics. The average of innovation measure $(P T C)$ is 420.245 (see Panel A in Table 2). Panel B shows workplace diversity policy measures. CEI has a 58.222 average value; about $89 \%$ of firm observations offer a sexual orientation nondiscrimination policy $(S O N D P) ; 61 \%$ of firm observations have a gender identity nondiscrimination policy (GINDP); domestic partner benefits are offered by $63 \%$ of firm observations $(D P B)$; and only $32 \%$ of the firm observations have transgender benefits policies (TG). The CEI score indicates whether a firm fully supports policies or only does so symbolically. In our sample, $39 \%$ of all firm observations score 100 points, suggesting that these firms engage in the best practices with their LGBT employees and provide support to the LGBT and non-LGBT workforce in creating a respectful and conducive workplace environment for all. Panel $\mathrm{C}$ shows that on average, the board size (Bsize) is 11.051; CEO duality (Duality) has the mean value 0.547 ; board independence (Bind) is $82.322 \%$; and the average number of board meetings (Ln_bmeeting) is 7.962. Panel D shows that size of the firm

\footnotetext{
${ }^{7}$ Generally, the fixed effects (FE) technique is suggested for panel data estimation in the presence of unobserved firm fixed effects (e.g. Pathan, 2009). However, this method (FE) may not be suitable for this study because it requires substantial variation in the variables to generate consistent and unbiased estimates. In our study, the variable of interest, CEI lacks substantial variations over time. Therefore, FE may provide imprecise estimation (Wooldridge, 2002: p.286). In addition, FE is not supported in a small number of firms over a limited time period, which is the case of our study $(n=398$ and $t=4)$ (Baltagi et al., 2005: p. 13).
} 
(Firm size) has an average value of 4.078; ROA shows 6.177 mean value; and Leverage has an average value of 0.256 . Tobin's $q$ has an average of 1.844 ; Insideown, a proxy for internal ownership, shows a mean value of $2.084 \%$; and capex has an average of -0.043 . Table $2 \mathrm{~A}$ shows the number and percentage of firms offering workplace diversity policies. For instance, about $96 \%$ of firms (386 firms) have SONDP; $76 \%$ of firms (306 firms) have GINDP; DPB and $T G$ are offered by $70 \%$ (281 firms) and 49\% (198 firms) of firms respectively. In terms of the combination of policies, $76 \%$ of firms (303 firms) have both SONDP and GINDP; $59 \%$ of firms (236 firms) have both GINDP and $D P B$, and only $43 \%$ of firms (173 firms) have $D P B$ and $T G$ policies.

[Insert Tables 2 and 2A about here]

Table 3 shows the correlations among variables used in our regression model to check the multicollinearity problem. All the variables measuring workplace diversity are positively correlated with the innovation variable, providing support to our hypothesis. In our sample, the highest correlation is among $C E I$ and dummy variables (SONDP, GINDP, DPB, and TG), highlighted in bold. As a general principle, a correlation higher than 0.70 may indicate a multicollinearity issue (Alam et al., 2019; Liu, Wei, \& Xie, 2014). However, we used highly correlated variables in separate regressions, instead of simultaneously in a model, and therefore, high correlation among these variables is not an issue for our study. The remaining variables report no correlation coefficient value higher than 0.70 . In addition, to test the potential effect of multicollinearity among these variables, we calculate the variance inflation factor (VIF). ${ }^{8}$ All the variables have a VIF of less than 1.35 and the overall mean value is $1.28 .{ }^{9}$ This suggests that multicollinearity is not an issue in the model.

[Insert Table 3 about here]

\footnotetext{
${ }^{8}$ We do not report VIF results in the interest of brevity.

${ }^{9}$ Lardaro (1993) suggests that multicollinearity can cause an issue if VIF exceeds 10.
} 


\section{Results and discussion}

\section{Main results: Workplace diversity policies and innovation}

We examined the impact of workplace diversity policies on firm innovation. Panel A in Table 4 presents the results of the baseline regressions using the OLS specification. We start our analysis (Column 1) by regressing the innovation (measured as the number of patents, trademarks, and copyrights granted) on the Corporate Equality Index (CEI, the umbrella measure) with industry and year effects. In Columns 2-5, we incorporate the measures of individual policies. For instance, Column 2 shows the effect of sexual orientation nondiscrimination (SONDP) policy; Column 3 illustrates the impact of gender identity nondiscrimination (GINDP) policy; Column 4 presents the impact of domestic partner benefits $(D P B)$ policy; and Column 5 shows the effect of transgender $(T G)$ policy on innovation.

In all the regressions, results suggest that workplace diversity policies have a significantly positive impact on firm innovation at the $10 \%$ or better level of significance. In addition, individual policies also positively affect innovation. The economic significance is also important. For example, an increase in CEI score by one (sample) standard deviation (i.e., using Table 2), increases innovation by approximately 0.38\% [CEI (37.738)×4.234/ PTC (420.425) $=0.380]$. In summary, there is consistent and statistically strong evidence that workplace diversity policies have a significantly positive impact on innovation across all the regressions. Overall, these findings support our hypothesis.

For robustness, we use OLS and one-year lagged specification, without controlling for firm and governance characteristics. We report results in Panel B in Table 4. Our results suggest that the $C E I$ and individual policies are positively and significantly associated with innovation across all the Columns (1-10). ${ }^{10}$ These findings further support our hypothesis. Overall, the

\footnotetext{
${ }^{10}$ We further apply restriction in our sample by including only those firms which have SONDP but not GINDP, $D P B$, or $T G$ and run regression analysis. Our results remain consistent.
} 
results confirm the imperative of Rawls' theory that if the workforce is treated equally and provided with conducive environment, it creates value for the firm.

[Insert Table 4 about here]

\section{Robustness checks}

In this section, we perform a number of sensitivity checks to ensure the robustness of our results. We specify: (i) alternative variables to measure innovation in addition to $P T C$, including patents, trademarks, and copyrights scaled by number of employees in the firm (PTC/Emp), PTC scaled by sales turnover (PTC/Sales), log of total research and development expenditure $\left(L n \_R \& D\right)$, and research and development expenditure scaled by sales turnover ( $R \& D /$ Sales); (ii) a different estimation technique (i.e. Tobit regression); (iii) excluding firm governance characteristics; and (iv) controlling for firm age and location, since both of these variables may affect firm equality policies depending on whether it is a new or established firm and the state location. ${ }^{11}$

Table 5 reports the results of the above-mentioned specifications based on Equation 1 in Panels A-D. The year and industry effects are included in all the regression specifications. We also include the control variables, as specified in Table 1, in all the regressions. We find that $C E I$ is positively associated with innovation across the four panels.

[Insert Table 5 about here]

\section{Endogeneity bias}

Our results in the previous section may face critique for potential endogeneity bias, due to a causal effect of diversity policies on firm outcomes (i.e. innovation). For instance, in order to create a conducive and creative workplace environment, managers who are sensitive to the benevolent effect of corporate diversity may hire more LGBT employees by creating LGBT-

\footnotetext{
${ }^{11}$ As a further robustness check, we also specify industry adjusted PTC, and industry adjusted sales turnover. Our results remain consistent.
} 
supportive policies that may ultimately foster innovation. Moreover, innovative firms may be responsive to external and societal trends in accepting LGBT employees into their workforce. Therefore, our main independent variable (CEI) may suffer from bias, and as a result, may not be systematically associated with our dependent variable (PTC). In this section, we address endogeneity concerns using the following two approaches: propensity score matching (PSM), and a dynamic panel data estimation technique - Generalized Method of Moments (GMM).

\section{Propensity score matching}

We use the propensity score matching estimator method (PSM) (e.g. Rosenbaum \& Rubin, 1983; Lennox, Francis, \& Wang, 2013) to test the change in the dependent variable (innovation), as a result of workplace diversity policies. First, we estimate the probability that a firm is involved in the best practices of having workplace diversity (LGBT-supportive) policies. We run a logistic regression for CEI_dummy (that equals 1 when the CEI score is greater than mean value and 0 otherwise - we treat firms with 1 as part of the treatment group and those with 0 as the control group) with the same explanatory variables as specified in Table 4 (i.e. Bsize, ROA, Leverage, etc.). ${ }^{12}$ Table 6 (Panel A) reports the pre-match logistic regression results. The pseudo R-square for the regression is high (0.221).

We also use the nearest neighbor approach to ensure that firms in the treatment and control groups are sufficiently identical. Notably, each firm in the treatment group is matched to a firm in the control group with the closest propensity score. In the case of multiple matches, we retain the pair for which the difference between the propensity scores of the two firms is the smallest. We further require that the maximum difference between the propensity score of each firm and its matched peer does not exceed $0.1 \%$ in absolute value. ${ }^{13}$

\footnotetext{
${ }^{12}$ As a robustness measure, we use the median to form CEI_dummy. Our results remain consistent.

${ }^{13} \mathrm{We}$ allow firms to be matched to multiple firms by changing the permissible difference in propensity scores to $1.0 \%$ and $0.5 \%$ in value, however we find consistent results (un-tabulated).
} 
To verify that the firms in the treatment and groups are indistinguishable in terms of observable characteristics, we conduct two diagnostic tests. The first test consists of reestimating the logit model for the post-match sample. The results in post-match (Panel A in Table 6) suggest that no coefficient is statistically significant, indicating that there are no distinguishable trends between the two groups. Moreover, coefficients in post-match are smaller in magnitude than those in the pre-match column, indicating the decline in the degree of freedom in the restricted sample. Finally, the pseudo R-square declines from 0.221 to 0.027 for the post-match sample. This suggests that propensity score matching removes all observable differences, other than the difference in the lower score for workplace diversity policies. The second test examines the differences in the mean of each observable characteristic between the treatment and the control firms. Panel B of Table 6 shows that none of the differences in the observable characteristics between the treatment and control groups are statistically significant. ${ }^{14}$ Overall, the diagnostic test suggests that the propensity score matching removes all of the observable differences in explanatory variables, other than $C E I$.

We report propensity score matching estimates in Panel C (Table 6). The results show that there are significant differences (significant at the 1\% level) in innovation between firms with LGBT-supportive policies and those without (symbolic). These findings suggest that an increase in innovation is attributable to the systematic difference in the workplace diversity policies.

\section{[Insert Table 6 about here]}

\section{Dynamic panel data estimation}

Second, we use dynamic panel estimation, which accounts for unobserved heterogeneity, simultaneity, and the dynamic relation between the $C E I$ and past innovation (Wintoki, Linck,

\footnotetext{
${ }^{14}$ Mean difference between the treatment and the control group is based on the average treatment effect on the treated (ATT).
} 
\& Netter, 2012; Abdallah, Goergen, \& O’Sullivan, 2015; Atif, Huang, \& Liu, 2019). The twostep 'system GMM' (Arellano \& Bover, 1995; Blundell \& Bond, 1998) uses first-differenced variables as instruments for the equations in levels. ${ }^{15}$ The estimations are robust to undetected heterogeneity, causality problems and dynamic endogeneity. The stability of the dynamic system GMM depends on two major conditions. The first condition is the serial independence of the residuals, where the first difference residuals should be serially correlated (ARl) by the means of their structure. However, residuals in the second difference should not be serially correlated (AR2). The second condition is the validity of instruments used in dynamic estimation. The Hansen J-statistic of over-identifying restrictions tests the null hypothesis of the instruments' validity. The insignificance of the Hansen J-statistic indicates the validity of instruments in the respective estimations. Finally, the number of instruments (i.e. 20) used in the model is less than in the panel (i.e. 398), which adds to the consistency of the Hansen Jstatistic.

The diagnostic test in Table 7 shows that the model is statistically well-fitted for first order autocorrelation $(A R 1)$, insignificant for second order autocorrelation (AR2), and for the Hansen J-statistic of over-identifying restrictions. The interpretation of the parameters on CEI and innovation remains quantitatively the same as in Table 4. For instance, CEI positively affects innovation. Hence, the system GMM supports our results, even after controlling for undetected heterogeneity, simultaneity bias and dynamic endogeneity.

[Insert Table 7 about here]

\section{Workplace diversity policies and firm performance}

In this section, we investigate whether workplace diversity policies affect a firm's performance. If firms tend towards implementing LGBT-supportive policies, in line with

15 The system GMM estimations are based on (Roodman, 2006), using Stata module 'xtabond2'. Refer to Roodman (2006) and Pathan (2009) for details on dynamic panel data estimations. 
external and societal norms, then one may expect a positive impact on firm value and performance consistent with the responsible firm hypothesis. We measure firm performance using Tobin's $q$ and ROS (net income scaled by sales turnover) following prior studies (e.g., Liu et al., 2014). We estimate the following regression model to examine the impact of $C E I$ and $P T C$ on firm performance.

$$
\begin{aligned}
& \text { Firm perf } f_{i, t}=\alpha+\beta_{1}(\text { Corporate_Equality })_{i, t}+\beta_{2}(\text { Innovation })_{i, t}+ \\
& \beta_{3}(\text { Corporate_Equality } \times \text { Innovation })_{i, t}+\beta_{4}(\text { Board_Characteristics })_{i, t}+
\end{aligned}
$$

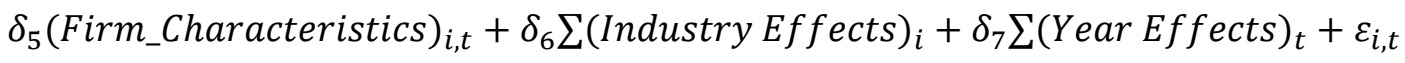

The dependent variable in this equation (firm perf) is measured by Tobin's $q$ and ROS. The independent variables are the same as specified in Table 1 and discussed in the above sections, except for the interaction between innovation and diversity policies (Corporate_Equality $\times$ Innovation) which is the main variable of interest. Table 8 reports the results using OLS and one-year lagged specifications for Tobin's $q$ and $R O S$, respectively. The interaction term shows a positive effect on firm performance. These results suggest a positive effect of workplace diversity policies and innovation on firm performance, which is significant at the $5 \%$ or better level of significance. These findings suggest that LGBT-supportive policies have a positive impact on firms' innovation that ultimately increases firm performance, indicating workplace diversity policies as one of the drivers of firm performance.

[Insert Table 8 about here]

\section{Conclusion}

Innovation is an important function of both accounting and management because it is linked to business performance and serves to accommodate market uncertainties a firm may face in its competitive environment. In this paper, using HRC data for large US firms from 2011-2014, we investigate the effect of $C E I$ score on firm innovation and find a significantly positive relationship. We also find a significantly positive relationship between individual anti- 
discriminatory policies and firm innovation. More specifically, we show that workplace diversity policies positively affect firm innovation, which ultimately leads to higher firm performance. Our findings are robust to alternative econometric specifications, alternative measures of innovation, and to individual policies. In a finer analysis, propensity score matching (PSM), and dynamic panel data estimation (system GMM), we further strengthen our finding that workplace diversity policies have a positive causal effect on innovation, and that these results are not due to omitted variables or causality issues. We have used Rawls' Theory of Justice (1971) to argue that firms have a greater ethical imperative to advance fairness and meritocratic values among employees and society at large. In addition, we have used the imperative of stakeholder theory to argue that LGBT-supportive policies in the firms are an important part of workplace diversity management, which should be communicated to all stakeholders.

Our paper has important implications not only for firms' workplace strategies, but also for developing diversity policies aimed at increasing innovation that may ultimately lead to better firm performance. The implications of our study are based on macro (overall CEI score) and micro (individual diversity policies) perspectives. Our results suggest that adoption of antidiscriminatory policies that aim to provide equal employment opportunities can have real economic benefits in terms of higher innovation and higher firm performance. Our findings are timely and important because, in the U.S., there is an ongoing debate around banning sexual orientation discrimination in the workplace across the country. Our findings may also trigger debate in similar markets around the globe to enhance disclosure on firms' LGBT workplace policies to gain comparable economic benefits.

Like most research, our study is subject to potential limitations. In particular, it is limited to a consideration of large firms in the U.S. This focus limits the ability to generalize to small firms and those outside the U.S., or not-for-profit organizations. Future studies may 
investigate this issue in the context of different types of organizations, and may shift the focus towards other developed or developing countries, since workplace diversity policies are increasingly advocated around the globe. 
Table 1. Variables definitions

\begin{tabular}{|c|c|c|}
\hline Notation & Variable name & Measure \\
\hline \multicolumn{3}{|c|}{ Panel A: Innovation } \\
\hline PTC & Patents, trademark and copyrights & Total patents, trademarks, and copyrights issued in a year \\
\hline PTC/Emp & $\begin{array}{l}\text { Patents, trademark and copyrights per } \\
\text { employee }\end{array}$ & Total patents, trademarks, and copyrights issued in a year divided by number of employees \\
\hline PTC/Sales & Patents, trademark and copyrights per sale & Total patents, trademarks, and copyrights issued in a year divided by total sales turnover \\
\hline Ln_R\&D & Research and development & Natural log of total research and development expenditure \\
\hline $\mathrm{R} \& \mathrm{D} / \mathrm{Sales}$ & Research and development per sales & Total research and development expenditures divided by total sales turnover \\
\hline \multicolumn{3}{|c|}{ Panel B: Corporate equality } \\
\hline CEI & Corporate equality index & $\begin{array}{l}\text { The score ranging from } 0 \text { to } 100 \text { with } 100 \text { being the top score based on firm treatment of individuals within the LGBT community } \\
\text { employees }\end{array}$ \\
\hline SONDP & Sexual orientation non-discrimination policy & A dummy variable equals 1 if firm has a sexual orientation non-discrimination policy and 0 otherwise \\
\hline GINDP & Gender-identity non-discrimination policy & A dummy variable equals 1 if firm has a gender-identity non-discrimination policy and 0 otherwise \\
\hline DPB & Domestic partner benefits & A dummy variable equals 1 if firm offers domestic partner benefits to its LGBT constituents and 0 otherwise \\
\hline TG & Transgender insurance & A dummy variable equals 1 if firm offers health benefits to transgender employees and 0 otherwise \\
\hline \multicolumn{3}{|c|}{ Panel C: Corporate governance } \\
\hline Bsize & Board size & The total number of directors on the firm's board \\
\hline Duality & CEO duality & A dummy variable equals 1 if the $\mathrm{CEO}$ is also the chairman of the board and 0 otherwise \\
\hline Bind & Board independence & The number of independent directors divided by the board size \\
\hline Ln_bmeeting & Board meetings & Log of the number of board meetings held in a year \\
\hline \multicolumn{3}{|c|}{ Panel D: Firm characteristics } \\
\hline Firm size & Size of firm & Natural log of total assets \\
\hline ROA & Return on assets & Firm net income divided by total assets \\
\hline Leverage & Leverage & The sum of short- and long-term debt divided by total assets \\
\hline Tobin's q & Growth opportunities & Market value of equity divided the book value of equity \\
\hline Insideown & Insider ownership & The percentage of share held by insiders in total outstanding capital \\
\hline Capex & Capital expenditure & Total capital expenditures divided by total assets \\
\hline
\end{tabular}

24 | P a g e 
Table 2. Descriptive statistics

\begin{tabular}{|c|c|c|c|c|c|c|}
\hline Variable & $\mathrm{N}$ & Mean & Std. Dev. & 1st Quartile & Median & 3rd Quartile \\
\hline \multicolumn{7}{|c|}{ Panel A: Innovation } \\
\hline PTC & 1592 & 420.425 & 2030.575 & 0 & 0 & 119.500 \\
\hline \multicolumn{7}{|c|}{ Panel B: Corporate equality } \\
\hline CEI & 1592 & 58.222 & 37.738 & 15 & 65 & 100 \\
\hline SONDP & 1592 & 0.889 & 0.314 & 1 & 1 & 1 \\
\hline GINDP & 1592 & 0.606 & 0.489 & 0 & 1 & 1 \\
\hline DPB & 1592 & 0.628 & 0.483 & 0 & 1 & 1 \\
\hline TG & 1592 & 0.321 & 0.467 & 0 & 0 & 1 \\
\hline \multicolumn{7}{|c|}{ Panel C: Corporate governance } \\
\hline Bsize & 1561 & 11.051 & 2.019 & 10 & 11 & 12 \\
\hline Duality & 1549 & 0.547 & 0.498 & 0 & 1 & 1 \\
\hline Bind & 1592 & 82.322 & 15.488 & 80 & 88.889 & 90.909 \\
\hline Ln_bmeeting & 1592 & 7.962 & 3.560 & 6 & 7 & 10 \\
\hline \multicolumn{7}{|c|}{ Panel D: Firm characteristics } \\
\hline Firm size & 1579 & 4.078 & 0.480 & 3.782 & 4.023 & 4.323 \\
\hline ROA & 1570 & 6.177 & 6.177 & 2.296 & 5.24 & 9.325 \\
\hline Leverage & 1577 & 0.256 & 0.219 & 0.118 & 0.225 & 0.360 \\
\hline Tobin's q & 1561 & 1.844 & 1.094 & 1.146 & 1.501 & 2.111 \\
\hline Insideown & 1592 & 2.084 & 4.384 & 0.312 & 0.642 & 1.708 \\
\hline Capex & 1577 & -0.043 & 0.053 & -0.058 & -0.029 & -0.013 \\
\hline
\end{tabular}

Table 2A. Descriptive statistics of workplace policies

\begin{tabular}{lrr}
\hline Variable & No. of firms & \% of firms \\
\hline SONDP & 386 & 0.960 \\
GINDP & 306 & 0.760 \\
DPB & 281 & 0.700 \\
TG & 198 & 0.490 \\
SONDP and GINDP & 303 & 0.760 \\
GINDP and DPB & 236 & 0.590 \\
DPB and TG & 173 & 0.430 \\
\hline
\end{tabular}

Tables 2 and 2A present the descriptive statistics. Refer Table 1 for variables definitions. 
Table 3. Correlation matrix

\begin{tabular}{|c|c|c|c|c|c|c|c|c|c|c|c|c|c|c|c|c|c|}
\hline & Variables & 1 & 2 & 3 & 4 & 5 & 6 & 7 & 8 & 9 & 10 & 11 & 12 & 13 & 14 & 15 & 16 \\
\hline 1 & PTC & 1.000 & & & & & & & & & & & & & & & \\
\hline 2 & CEI & 0.128 & 1.000 & & & & & & & & & & & & & & \\
\hline 3 & SONDP & 0.051 & 0.527 & 1.000 & & & & & & & & & & & & & \\
\hline 4 & GINDP & 0.105 & 0.828 & 0.415 & 1.000 & & & & & & & & & & & & \\
\hline 5 & DPB & 0.105 & 0.864 & 0.423 & 0.646 & 1.000 & & & & & & & & & & & \\
\hline 6 & $\mathrm{TG}$ & 0.109 & 0.703 & 0.231 & 0.540 & 0.485 & 1.000 & & & & & & & & & & \\
\hline 7 & Bsize & 0.092 & 0.214 & 0.117 & 0.160 & 0.181 & 0.136 & 1.000 & & & & & & & & & \\
\hline 8 & Duality & 0.076 & 0.061 & 0.024 & 0.038 & 0.043 & 0.041 & 0.049 & 1.000 & & & & & & & & \\
\hline 9 & Bind & 0.060 & 0.140 & 0.083 & 0.096 & 0.167 & 0.069 & 0.110 & 0.173 & 1.000 & & & & & & & \\
\hline 10 & Ln_bmeeting & 0.055 & 0.106 & 0.044 & 0.069 & 0.068 & 0.143 & 0.127 & -0.023 & 0.175 & 1.000 & & & & & & \\
\hline 11 & Firm size & 0.205 & 0.244 & 0.150 & 0.173 & 0.181 & 0.240 & 0.344 & 0.155 & 0.098 & 0.091 & 1.000 & & & & & \\
\hline 12 & ROA & 0.036 & -0.005 & -0.021 & -0.018 & 0.007 & 0.019 & -0.124 & 0.003 & -0.068 & -0.263 & 0.006 & 1.000 & & & & \\
\hline 13 & Leverage & 0.002 & -0.091 & 0.056 & -0.087 & -0.053 & -0.088 & 0.022 & -0.028 & -0.050 & 0.026 & -0.066 & -0.004 & 1.000 & & & \\
\hline 14 & Tobin's q & 0.028 & 0.051 & -0.026 & 0.045 & 0.067 & 0.010 & -0.161 & -0.010 & -0.096 & -0.231 & -0.116 & 0.486 & 0.204 & 1.000 & & \\
\hline 15 & Insideown & -0.052 & -0.010 & -0.019 & 0.002 & -0.021 & 0.023 & -0.098 & -0.103 & -0.284 & -0.098 & -0.149 & -0.008 & -0.003 & 0.062 & 1.000 & \\
\hline 16 & Capex & 0.049 & 0.114 & 0.004 & 0.062 & 0.091 & 0.114 & 0.098 & -0.050 & 0.043 & 0.070 & 0.001 & -0.052 & -0.151 & -0.044 & -0.009 & 1.000 \\
\hline
\end{tabular}

Table 3 shows the correlation matrix. Refer Table 1 for variables definitions.

26 | $P$ a g e 
Table 4 Workplace diversity policies and innovation

\begin{tabular}{|c|c|c|c|c|c|}
\hline Variable & & & PTC & & \\
\hline Panel A & (1) & (2) & (3) & (4) & (5) \\
\hline CEI & $\begin{array}{r}4.234 * * * * \\
(2.698)\end{array}$ & & & & \\
\hline SONDP & & $\begin{array}{r}167.841^{*} \\
(1.985)\end{array}$ & & & \\
\hline GINDP & & & $\begin{array}{r}303.389 * * * \\
(2.658)\end{array}$ & & \\
\hline DPB & & & & $\begin{array}{r}251.708 * * \\
(2.145)\end{array}$ & \\
\hline TG & & & & & $\begin{array}{r}273.557 * * \\
(2.253)\end{array}$ \\
\hline Bsize & $\begin{array}{r}16.916 \\
(0.596)\end{array}$ & $\begin{array}{l}23.931 \\
(0.846)\end{array}$ & $\begin{array}{r}18.985 \\
(0.671)\end{array}$ & $\begin{array}{r}19.842 \\
(0.700)\end{array}$ & $\begin{array}{r}23.157 \\
(0.820)\end{array}$ \\
\hline Duality & $\begin{array}{r}227.220 * * \\
(2.100)\end{array}$ & $\begin{array}{r}241.226 * * \\
(2.227)\end{array}$ & $\begin{array}{r}231.548 * * \\
(2.141)\end{array}$ & $\begin{array}{r}236.867 * * \\
(2.189)\end{array}$ & $\begin{array}{r}236.421 * * \\
(2.185)\end{array}$ \\
\hline Bind & $\begin{array}{r}4.580 \\
(0.776)\end{array}$ & $\begin{array}{r}6.253 \\
(1.064)\end{array}$ & $\begin{array}{r}5.296 \\
(0.901)\end{array}$ & $\begin{array}{r}4.614 \\
(0.777)\end{array}$ & $\begin{array}{r}5.772 \\
(0.983)\end{array}$ \\
\hline Ln_bmeeting & $\begin{array}{r}17.571 \\
(1.069)\end{array}$ & $\begin{array}{r}21.161 \\
(1.290)\end{array}$ & $\begin{array}{r}18.929 \\
(1.154)\end{array}$ & $\begin{array}{r}19.917 \\
(1.215)\end{array}$ & $\begin{array}{r}16.489 \\
(0.998)\end{array}$ \\
\hline Firm size & $\begin{array}{r}559.639 * * * \\
(4.425)\end{array}$ & $\begin{array}{r}632.386^{* * * *} \\
(5.123)\end{array}$ & $\begin{array}{r}586.689 * * * \\
(4.719)\end{array}$ & $\begin{array}{r}596.459 * * * \\
(4.787)\end{array}$ & $\begin{array}{r}576.474 * * * * \\
(4.564)\end{array}$ \\
\hline ROA & $\begin{array}{r}7.608 \\
(0.627)\end{array}$ & $\begin{array}{r}5.503 \\
(0.453)\end{array}$ & $\begin{array}{r}7.966 \\
(0.656)\end{array}$ & $\begin{array}{r}6.675 \\
(0.550)\end{array}$ & $\begin{array}{r}5.786 \\
(0.477)\end{array}$ \\
\hline Leverage & $\begin{array}{r}-209.622 \\
(-0.814)\end{array}$ & $\begin{array}{r}-283.986 \\
(-1.099)\end{array}$ & $\begin{array}{r}-206.062 \\
(-0.800)\end{array}$ & $\begin{array}{r}-240.680 \\
(-0.936)\end{array}$ & $\begin{array}{r}-236.763 \\
(-0.920)\end{array}$ \\
\hline Tobin's q & $\begin{array}{l}-15.777 \\
(-0.223)\end{array}$ & $\begin{array}{r}6.440 \\
(0.091)\end{array}$ & $\begin{array}{l}-13.403 \\
(-0.189)\end{array}$ & $\begin{array}{r}-9.428 \\
(-0.133)\end{array}$ & $\begin{array}{r}-3.215 \\
(-0.046)\end{array}$ \\
\hline Insideown & $\begin{array}{r}-5.980 \\
(-0.479)\end{array}$ & $\begin{array}{r}-4.217 \\
(-0.338)\end{array}$ & $\begin{array}{r}-5.437 \\
(-0.436)\end{array}$ & $\begin{array}{r}-5.125 \\
(-0.410)\end{array}$ & $\begin{array}{r}-6.031 \\
(-0.482)\end{array}$ \\
\hline Capex & $\begin{array}{r}1299.188 \\
(1.184)\end{array}$ & $\begin{array}{r}1165.873 \\
(1.061)\end{array}$ & $\begin{array}{r}1336.538 \\
(1.217)\end{array}$ & $\begin{array}{r}1281.109 \\
(1.166)\end{array}$ & $\begin{array}{r}1167.524 \\
(1.065)\end{array}$ \\
\hline Constant & $\begin{array}{r}-729.857 * * * \\
(-3.163)\end{array}$ & $\begin{array}{r}-158.642^{* * *} \\
(-3.708)\end{array}$ & $\begin{array}{r}-877.784 * * * \\
(-3.365)\end{array}$ & $\begin{array}{r}-858.258^{* * * *} \\
(-3.322)\end{array}$ & $\begin{array}{r}-751.883 * * * \\
(-3.173)\end{array}$ \\
\hline $\begin{array}{l}\text { Industry effects } \\
\text { Year effects }\end{array}$ & $\begin{array}{l}\mathrm{Y} \\
\mathrm{Y}\end{array}$ & $\begin{array}{l}\mathrm{Y} \\
\mathrm{Y}\end{array}$ & $\begin{array}{l}\mathrm{Y} \\
\mathrm{Y}\end{array}$ & $\begin{array}{l}\mathrm{Y} \\
\mathrm{Y}\end{array}$ & $\begin{array}{l}\mathrm{Y} \\
\mathrm{Y}\end{array}$ \\
\hline $\mathrm{N}$ & 1528 & 1528 & 1528 & 1528 & 1528 \\
\hline Adj. R-sq & 0.189 & 0.195 & 0.198 & 0.187 & 0.188 \\
\hline
\end{tabular}

27 | $P$ a g e 


\begin{tabular}{|c|c|c|c|c|c|c|c|c|c|c|}
\hline Variable & & & & & & $\mathrm{TC}$ & & & & \\
\hline Panel B & $\begin{array}{l}\text { OLS } \\
\text { (1) }\end{array}$ & $\begin{array}{l}\text { Lagged } \\
\text { (2) }\end{array}$ & $\begin{array}{l}\text { OLS } \\
\text { (3) }\end{array}$ & $\begin{array}{l}\text { Lagged } \\
\text { (4) }\end{array}$ & $\begin{array}{l}\text { OLS } \\
\text { (5) }\end{array}$ & $\begin{array}{l}\text { Lagged } \\
\text { (6) }\end{array}$ & $\begin{array}{l}\text { OLS } \\
\text { (7) }\end{array}$ & $\begin{array}{l}\text { Lagged } \\
\text { (8) }\end{array}$ & $\begin{array}{l}\text { OLS } \\
(9)\end{array}$ & $\begin{array}{l}\text { Lagged } \\
\text { (10) }\end{array}$ \\
\hline CEI & $\begin{array}{l}6.402 * * * \\
(4.550)\end{array}$ & $\begin{array}{l}5.635^{* * * *} \\
(4.113)\end{array}$ & & & & & & & & \\
\hline SONDP & & & $\begin{array}{l}306.882 * \\
(1.902)\end{array}$ & $\begin{array}{l}267.675^{*} \\
(1.669)\end{array}$ & & & & & & \\
\hline GINDP & & & & & $\begin{array}{l}422.472 * * * \\
(3.952)\end{array}$ & $\begin{array}{l}354.685 * * * \\
(3.377)\end{array}$ & & & & \\
\hline DPB & & & & & & & $\begin{array}{l}388.083 * * * \\
(3.563)\end{array}$ & $\begin{array}{l}375.059 * * * \\
(3.530)\end{array}$ & & \\
\hline TG & & & & & & & & & $\begin{array}{l}441.072 * * * \\
(3.955)\end{array}$ & $\begin{array}{l}365.387 * * * \\
(3.310)\end{array}$ \\
\hline Constant & $\begin{array}{l}628.803^{* * *} \\
(2.032)\end{array}$ & $\begin{array}{l}-169.758 \\
(-0.341)\end{array}$ & $\begin{array}{l}1166.111 * * \\
(2.248)\end{array}$ & $\begin{array}{l}-48.687 \\
(-0.090)\end{array}$ & $\begin{array}{l}1167.429 * * \\
(2.315)\end{array}$ & $\begin{array}{l}-87.797 \\
(-0.171)\end{array}$ & $\begin{array}{l}968.733^{*} \\
(1.917)\end{array}$ & $\begin{array}{l}-167.019 \\
(-0.331)\end{array}$ & $\begin{array}{l}986.305^{*} \\
(1.959)\end{array}$ & $\begin{array}{l}-29.615 \\
(-0.060)\end{array}$ \\
\hline Industry effects & $\mathrm{Y}$ & $\mathrm{Y}$ & $\mathrm{Y}$ & $\mathrm{Y}$ & $\mathrm{Y}$ & $\mathrm{Y}$ & $\mathrm{Y}$ & $\mathrm{Y}$ & $\mathrm{Y}$ & $\mathrm{Y}$ \\
\hline Year effects & $\mathrm{Y}$ & $\mathrm{Y}$ & $\mathrm{Y}$ & $\mathrm{Y}$ & $\mathrm{Y}$ & $\mathrm{Y}$ & $\mathrm{Y}$ & $\mathrm{Y}$ & $\mathrm{Y}$ & $\mathrm{Y}$ \\
\hline $\mathrm{N}$ & 1592 & 1591 & 1592 & 1591 & 1592 & 1591 & 1592 & 1591 & 1592 & 1591 \\
\hline Adj. R-sq & 0.261 & 0.258 & 0.210 & 0.249 & 0.257 & 0.241 & 0.255 & 0.219 & 0.271 & 0.154 \\
\hline
\end{tabular}

This table presents the regression results of model (1):

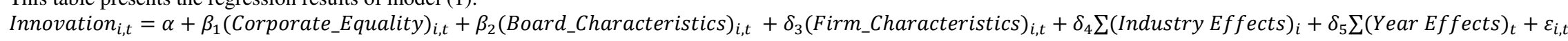

where innovation is measured by patents, trademarks and copyrights grants (PTC). Corporate Equality Index (CEI) is a measure of diversity policies published by Human Rights Campaign (HRC). Panel A Columns 1 presents the results of CEI on innovation. Columns $2-5$ present the results of corporate equality individual policies effect on innovation. Panel B shows the using OLS and one-year lagged variables on innovation without including control variables. Robust $t$-statistics are shown in parentheses. Standardized beta coefficients are reported. $* * *, * *, *$ denote statistical significance at the $1 \%, 5 \%$ and $10 \%$ level, respectively. All variables are defined in Table 1. 
Table 5. Robustness analysis

\begin{tabular}{|c|c|c|c|c|c|}
\hline Variable & PTC & PTC/Emp & PTC/Sales & Ln_R\&D & R\&D/Sales \\
\hline \multicolumn{6}{|l|}{ Panel A } \\
\hline \multicolumn{6}{|c|}{ OLS regression $(N=1,592)$} \\
\hline \multirow[t]{2}{*}{ CEI } & $4.234 * * *$ & $0.005 * *$ & $0.001 * * *$ & $0.089 * * *$ & $0.020 * * *$ \\
\hline & (2.698) & $(2.040)$ & (3.714) & (4.001) & $(2.301)$ \\
\hline Controls & Yes & Yes & Yes & Yes & Yes \\
\hline Industry effects & Yes & Yes & Yes & Yes & Yes \\
\hline Year effects & Yes & Yes & Yes & Yes & Yes \\
\hline \multicolumn{6}{|c|}{ Panel B } \\
\hline \multicolumn{6}{|c|}{ Tobit regression $(N=1,592)$} \\
\hline \multirow[t]{2}{*}{ CEI } & $9.017 * * *$ & $0.001 *$ & $0.003 * * *$ & $0.008 * * *$ & $0.0403 * *$ \\
\hline & (3.004) & $(1.990)$ & $(3.640)$ & $(3.167)$ & $(2.231)$ \\
\hline Controls & Yes & Yes & Yes & Yes & Yes \\
\hline Industry effects & Yes & Yes & Yes & Yes & Yes \\
\hline Year effects & Yes & Yes & Yes & Yes & Yes \\
\hline \multicolumn{6}{|l|}{ Panel C } \\
\hline \multicolumn{6}{|c|}{ Excluding governance characteristics $(N=1,592)$} \\
\hline \multirow[t]{2}{*}{ CEI } & $3.722 * * *$ & $0.002 *$ & $0.001 * * *$ & $0.009 * * *$ & $0.021 * * *$ \\
\hline & $(2.514)$ & $(1.921)$ & (3.871) & $(4.572)$ & $(4.660)$ \\
\hline Other controls & Yes & Yes & Yes & Yes & Yes \\
\hline Industry effects & Yes & Yes & Yes & Yes & Yes \\
\hline Year effects & Yes & Yes & Yes & Yes & Yes \\
\hline \multicolumn{6}{|c|}{ Panel D } \\
\hline \multicolumn{6}{|c|}{ Controlling for firm age, and location $(N=1,592)$} \\
\hline \multirow[t]{2}{*}{ CEI } & $3.872 * *$ & $0.013 * *$ & $0.010 * * *$ & $0.019 * *$ & $0.019 * *$ \\
\hline & $(2.164)$ & $(2.040)$ & $(2.543)$ & $(2.020)$ & $(2.011)$ \\
\hline Controls & Yes & Yes & Yes & Yes & Yes \\
\hline Industry effects & Yes & Yes & Yes & Yes & Yes \\
\hline Year effects & Yes & Yes & Yes & Yes & Yes \\
\hline
\end{tabular}

$29 \mid \mathrm{P}$ a g e 
Table 6. Propensity score matching

\begin{tabular}{|c|c|c|}
\hline Panel A & Pre-match & Post-match \\
\hline Variable & \multicolumn{2}{|c|}{ CEI_dummy } \\
\hline \multirow[t]{2}{*}{ Bsize } & $0.160 * * *$ & 0.004 \\
\hline & (4.493) & $(0.143)$ \\
\hline \multirow[t]{2}{*}{ Duality } & $0.319 * *$ & -0.078 \\
\hline & (2.462) & $(-0.692)$ \\
\hline \multirow[t]{2}{*}{ Bind } & $0.031 * * *$ & 0.008 \\
\hline & (4.222) & (1.229) \\
\hline \multirow[t]{2}{*}{ Ln_bmeeting } & $0.064 * * *$ & 0.029 \\
\hline & (3.054) & $(1.728)$ \\
\hline \multirow[t]{2}{*}{ Firm size } & $1.320 * * *$ & 0.269 \\
\hline & (8.264) & $(1.125)$ \\
\hline \multirow[t]{2}{*}{ ROA } & $-0.056 * * *$ & 0.012 \\
\hline & $(-3.647)$ & $(1.051)$ \\
\hline \multirow[t]{2}{*}{ Leverage } & $-1.202 * * *$ & -0.064 \\
\hline & $(-3.546)$ & $(-0.209)$ \\
\hline \multirow[t]{2}{*}{ Tobin's q } & $0.474 * * *$ & 0.103 \\
\hline & $(5.131)$ & $(1.511)$ \\
\hline \multirow[t]{2}{*}{ Insideown } & 0.022 & 0.001 \\
\hline & (1.397) & $(0.074)$ \\
\hline \multirow[t]{2}{*}{ Capex } & $-3.377 * *$ & -4.499 \\
\hline & $(-2.391)$ & $(-1.710)$ \\
\hline \multirow[t]{2}{*}{ Constant } & $-9.680 * * *$ & -1.906 \\
\hline & $(-9.219)$ & $(-1.725)$ \\
\hline Industry effects & $\mathrm{Y}$ & $\mathrm{Y}$ \\
\hline Year effects & $\mathrm{Y}$ & $\mathrm{Y}$ \\
\hline $\mathrm{N}$ & 1,528 & 828 \\
\hline Pseudo R-sq & 0.221 & 0.027 \\
\hline
\end{tabular}

Panel B: Difference in firm characteristics

\begin{tabular}{lrrrr}
\hline Variable & Treatment & Control & Difference & $t$-stat \\
\hline Bsize & 11.464 & 11.158 & 0.306 & 1.991 \\
Duality & 0.584 & 0.608 & -0.024 & -0.611 \\
Bind & 85.532 & 85.192 & 0.341 & 0.441 \\
Ln_bmeeting & 8.413 & 8.071 & 0.341 & 1.360 \\
Firm size & 4.174 & 4.122 & 0.052 & 1.450 \\
ROA & 6.186 & 5.916 & 0.270 & 0.510 \\
Leverage & 0.234 & 0.236 & -0.001 & -0.070 \\
Tobin's q & 1.916 & 2.108 & -0.191 & -1.160 \\
Insideown & 1.995 & 2.087 & -0.091 & -0.240 \\
Capex & -0.038 & -0.043 & 0.004 & 1.240 \\
\hline
\end{tabular}

Panel C: Propensity score estimator

\begin{tabular}{lrrrr}
\hline Variable & Treatment & Control & Difference & $t$-stat \\
\hline PTC & 653.386 & 426.312 & $227.074 * * *$ & 2.139 \\
\hline
\end{tabular}

The table presents the results of endogeneity test, propensity score matching in three panels. Panel A shows the pre-matchand post-match results and Panel B presents the difference in firm characteristics for the matched sample and Panel C reports propensity score estimators. Standardized beta coefficients are reported. $* * *, * *$ denote statistical significance at the $1 \%$, $5 \%$ and $10 \%$ level, respectively. All variables are defined in Table 1. 
Table 7. Generalized Method of Moments

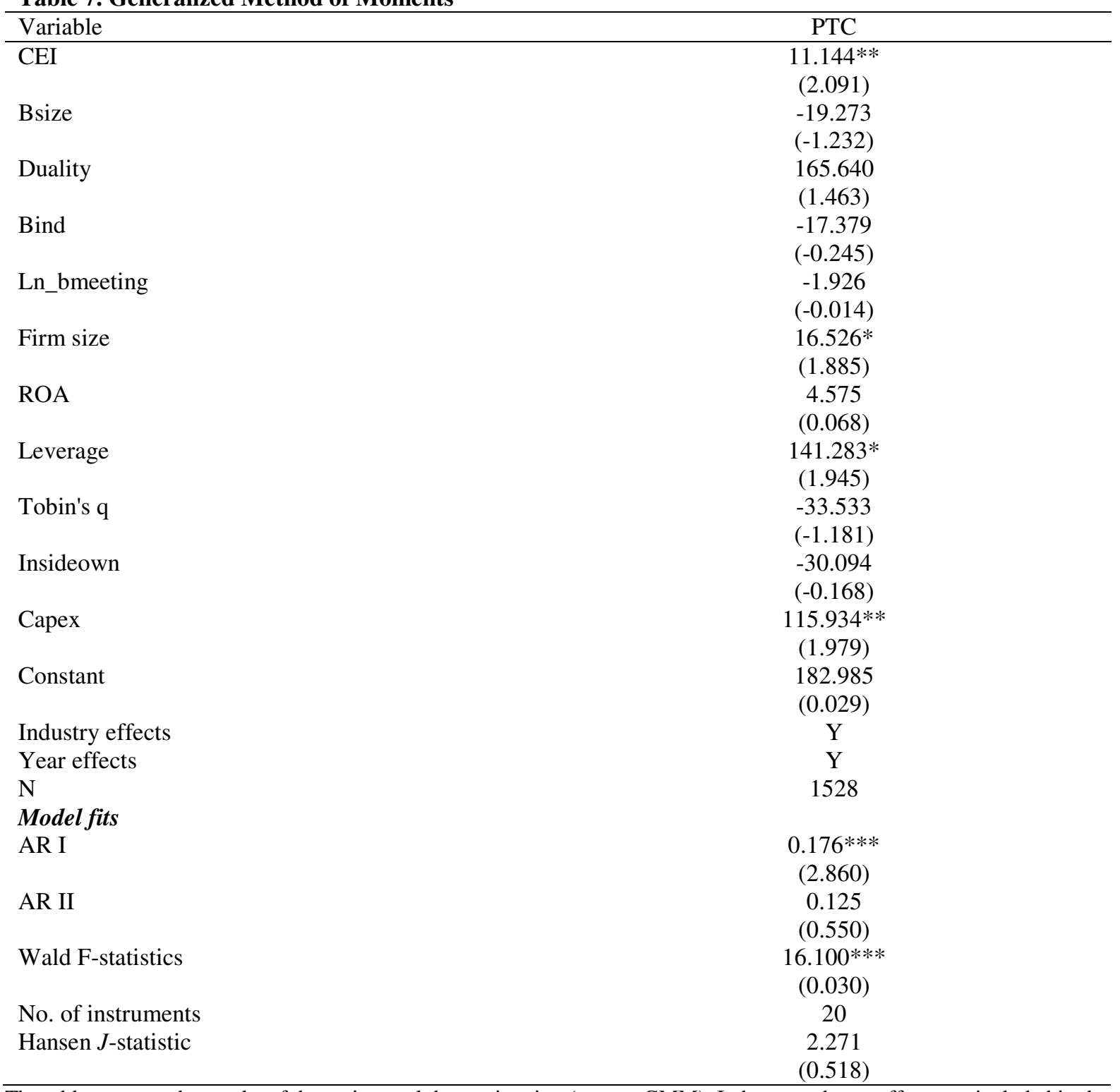

The table presents the results of dynamic panel data estimation (system GMM). Industry and year effects are included in the regression. Standardized beta coefficients are reported. $* * *, * * *$ denotes statistical significance at the $1 \%, 5 \%$ and $10 \%$ level, respectively. All variables are defined in Table 1. 
Table 8. Workplace diversity policies, innovation, and firm performance

\begin{tabular}{|c|c|c|c|c|}
\hline Variable & Tobin's q & Lagged Tobin's q & ROS & Lagged ROS \\
\hline \multirow[t]{2}{*}{ CEI } & $0.001 *$ & $0.003 * * *$ & $0.002 * *$ & $0.013 * *$ \\
\hline & (1.990) & (5.110) & $(2.190)$ & $(2.005)$ \\
\hline \multirow[t]{2}{*}{ PTC } & $0.001 * *$ & $0.001 * *$ & $1.320 * *$ & -1.200 \\
\hline & (2.110) & $(2.041)$ & $(2.190)$ & $(0.090)$ \\
\hline \multirow[t]{2}{*}{ CEI $\times$ PTC } & $1.320 * *$ & $1.220 * * *$ & $1.580 * *$ & $3.001 * *$ \\
\hline & $(2.181)$ & $(2.480)$ & $(2.120)$ & $(2.105)$ \\
\hline \multirow[t]{2}{*}{ Bsize } & $-0.088 * * *$ & $-0.044 * * *$ & 0.006 & 0.001 \\
\hline & $(-7.010)$ & $(-3.540)$ & $(0.530)$ & $(0.081)$ \\
\hline \multirow[t]{2}{*}{ Duality } & 0.018 & 0.058 & -0.008 & 0.004 \\
\hline & $(0.038)$ & $(1.220)$ & $(-0.180)$ & $(0.670)$ \\
\hline \multirow[t]{2}{*}{ Bind } & -0.002 & -0.002 & -0.001 & $-0.001 *$ \\
\hline & $(-0.001)$ & $(-0.900)$ & $(-0.720)$ & $(-0.600)$ \\
\hline \multirow[t]{2}{*}{ Ln_bmeeting } & $-0.047 * * *$ & $-0.020 * * *$ & $0.001 * * *$ & $0.001^{*}$ \\
\hline & $(-6.790)$ & $(-2.730)$ & $(2.410)$ & (1.192) \\
\hline \multirow[t]{2}{*}{ Firm size } & $-0.913 * * *$ & $-0.303 * * *$ & $-0.087 * * *$ & $-0.086^{* * *}$ \\
\hline & $(-13.921)$ & $(-5.530)$ & $(-12.250)$ & $(-9.660)$ \\
\hline \multirow[t]{2}{*}{ ROA } & $0.201 * * *$ & $0.120 * * *$ & $0.011 * * *$ & $0.006 * * *$ \\
\hline & (9.109) & $(14.130)$ & (20.73) & $(9.791)$ \\
\hline \multirow[t]{2}{*}{ Leverage } & $0.833 * * *$ & $1.240 * * *$ & $0.074 * * *$ & $0.066 * * *$ \\
\hline & $(7.651)$ & (11.160) & $(6.570)$ & $(4.661)$ \\
\hline \multirow[t]{2}{*}{ Tobin's q } & & & $-0.017 * * *$ & -0.001 \\
\hline & & & $(-5.380)$ & $(-0.013)$ \\
\hline \multirow[t]{2}{*}{ Insideown } & -0.004 & 0.008 & $0.001 * *$ & 0.001 \\
\hline & $(-0.080)$ & (1.640) & $(2.130)$ & (1.540) \\
\hline \multirow[t]{2}{*}{ Capex } & -0.628 & $0.883^{*}$ & -0.036 & -0.517 \\
\hline & $(-1.131)$ & (1.960) & $(-0.760)$ & $(-0.849)$ \\
\hline \multirow[t]{2}{*}{ Constant } & $5.001 * * *$ & $2.712 * * *$ & $1.054 * *$ & $0.385^{* * *}$ \\
\hline & (10.970) & $(9.071)$ & $(2.042)$ & (6.930) \\
\hline Industry effects & $\mathrm{Y}$ & $\mathrm{Y}$ & $\mathrm{Y}$ & $\mathrm{Y}$ \\
\hline Year effects & $\mathrm{Y}$ & $\mathrm{Y}$ & $\mathrm{Y}$ & $\mathrm{Y}$ \\
\hline $\mathrm{N}$ & 1528 & 1327 & 1528 & 1327 \\
\hline Adj. R-sq & 0.380 & 0.423 & 0.440 & 0.344 \\
\hline
\end{tabular}

This table presents the results of innovation, CEI (interaction term), and firm performance measured by Tobin's $q$ and ROS as dependant variables using OLS and one-year lagged specifications respectively. Industry and year effects are included in all the regressions. Robust $t$-statistics are shown in parentheses. Standardized beta coefficients are reported. ***,**, * denote statistical significance at the $1 \%, 5 \%$ and $10 \%$ level, respectively. All control variables are defined in Table 1 .

\section{Compliance with Ethical Standards}

\section{Conflict of interest}

All four authors declare that they have no conflict of interest.

Ethical Approval

This article does not contain any studies with human participants or animals performed by any of the authors. 


\section{References:}

Abdallah, W., Goergen, M., \& O'Sullivan, N. (2015). Endogeneity: How failure to correct for it can cause wrong inferences and some remedies. British Journal of Management, 26(4), 791-804.

Alam, M. S., Atif, M., Chien-Chi, C., \& Soytaş, U. (2019). Does corporate R\&D investment affect firm environmental performance? Evidence from G-6 countries. Energy Economics, 78, 401-411.

Arellano, M., \& Bover, O. (1995). Another look at the instrumental variable estimation of error-components models. Journal of Econometrics, 68(1), 29-51.

Atif, M., Huang, A., \& Liu, B. (2019). Effect of say on pay on CEO compensation and spillover effect on corporate cash holdings: Evidence from Australia. Pacific-Basin Finance Journal.

Badgett, M. L. (1995). The wage effects of sexual orientation discrimination. Industrial and Labor Relations Review, 48(4), 726-739.

Badgett, M. V., Lau, H., Sears, B., \& Ho, D. (2007). Bias in the workplace: Consistent evidence of sexual orientation and gender identity discrimination.

Baltagi, B. H., Bratberg, E., \& Holmås, T. H. (2005). A panel data study of physicians' labor supply: the case of Norway. Health Economics, 14(10), 1035-1045.

Baker, H. K., \& Anderson, R. (Eds.). (2010). Corporate governance: A synthesis of theory, research, and practice (Vol. 8). John Wiley \& Sons.

Barbulescu, R., \& Bidwell, M. (2013). Do women choose different jobs from men? Mechanisms of application segregation in the market for managerial workers. Organization Science, 24(3), 737-756.

Beckley, H. R. (1986). A Christian affirmation of Rawls's idea of justice as fairness-part II. Journal of Religious Ethics, 14(2), 229.

Bidwell, M., Briscoe, F., Fernandez-Mateo, I., \& Sterling, A. (2013). The employment relationship and inequality: How and why changes in employment practices are reshaping rewards in organizations. Academy of Management Annals, 7(1), 61-121.

Blundell, R., \& Bond, S. (1998). Initial conditions and moment restrictions in dynamic panel data models. Journal of Econometrics, 87(1), 115-143.

Bond, D., \& Park, J. C. (1991). An empirical test of Rawls's theory of justice: A second approach, in Korea and the United States. Simulation \& Gaming, 22(4), 443-462.

Bonaventura, L., \& Biondo, A. E. (2016). Disclosure of sexual orientation in the USA and its consequences in the workplace. International Journal of Social Economics, 43(11), $1115-1123$.

Briscoe, F., Chin, M. K., \& Hambrick, D. C. (2014). CEO ideology as an element of the corporate opportunity structure for social activists. Academy of Management Journal, 57(6), 1786-1809.

Burchell, S., Clubb, C., Hopwood, A., Hughes, J., \& Nahapiet, J. (1980). The roles of accounting in organizations and society. Accounting, Organizations and Society, 5(1), 527.

CEI Report 2015. Corporate Equality Index 2018. Human Rights Campaign Foundation, USA.

Chapman, J. W. (1975). Rawls' theory of justice. American Political Science Review, 69(2), 588-593.

Chen, J., Leung, W. S., \& Goergen, M. (2017). The impact of board gender composition on dividend payouts. Journal of Corporate Finance, 43, 86-105.

Cohen, M. A. (2010). The narrow application of Rawls in business ethics: A political conception of both stakeholder theory and the morality of markets. Journal of Business Ethics, 97(4), 563-579. 
Colgan, F. (2011). Equality, diversity and corporate responsibility: Sexual orientation and diversity management in the UK private sector. Equality, Diversity \& Inclusion, 30(8), 719-734.

Cook, A., \& Glass, C. (2016). Do women advance equity? The effect of gender leadership composition on LGBT-friendly policies in American firms. Human Relations, 69(7), 1431-1456.

Cordes, C. L. (2012). The business case for offering domestic partner benefits. Compensation \& Benefits Review, 44(2), 110-116.

De Hart, J. S. (1994). Equality challenged: Equal rights and sexual difference. Journal of Policy History, 6(1), 40-72.

Dent, J. F. (1990). Strategy, organization and control: Some possibilities for accounting research. Accounting, Organizations and Society, 15(1-2), 3-25.

Donaldson, T., \& Preston, L. E. (1995). The stakeholder theory of the corporation: Concepts, evidence, and implications. Academy of Management Review, 20(1), 65-91.

Drydakis, N. (2009). Sexual orientation discrimination in the labour market. Labour Economics, 16(4), 364-372.

Ezzamel, M., \& Bourn, M. (1990). The roles of accounting information systems in an organization experiencing financial crisis. Accounting, Organizations and Society, 15(5), 399-424.

Fama, E. F., \& Jensen, M. C. (1983). Separation of ownership and control. The Journal of Law and Economics, 26(2), 301-325.

Fang, V. W., Tian, X., \& Tice, S. (2014). Does stock liquidity enhance or impede firm innovation? The Journal of Finance, 69(5), 2085-2125.

Fieseler, C., Fleck, M., \& Meckel, M. (2010). Corporate social responsibility in the blogosphere. Journal of Business Ethics, 91(4), 599-614.

Francoeur, C., Labelle, R., \& Sinclair-Desgagné, B. (2008). Gender diversity in corporate governance and top management. Journal of Business Ethics, 81(1), 83-95.

Forbes Insights (2011). Global Diversity and inclusion Fostering Innovation Through a Diverse Workforce. Retrieved April 2, 2011 from https://i.forbesimg.com/forbesinsights/StudyPDFs/Innovation_Through_Diversity.pdf

Freeman, R. E. (1984). Strategic management: A stakeholder approach. Boston, MA: Pitman.

Freeman, S. (2006). The law of peoples, social cooperation, human rights, and distributive justice. Social Philosophy and Policy, 23(1), 29-68.

Gates, G. J. (2011). How many people are lesbian, gay, bisexual and transgender? Los Angeles, CA: Williams Institute, University of California, Los Angeles School of Law. Retrieved March 26, 2018 from http://williamsinstitute.law.ucla.edu/wpcontent/uploads/Gates-How-Many-People-LGBT-Apr-2011.pdf

Gates, G. J. (2012). LGBT Identity: A demographer's perspective. Loyola of Los Angeles Law Review, 45, 693-714.

Gavrilovic, V. (2016). Toleration and pluralism: an analysis of the contemporary debate on toleration and its practical implications on LGBT social movements and advocancy groups.

Grobler, B. R., Moloi, K. C., Loock, C. F., Bisschoff, T. C., \& Mestry, R. J. (2006). Creating a school environment for the effective management of cultural diversity. Educational Management Administration \& Leadership, 34(4), 449-472.

Gupta, A., Briscoe, F., \& Hambrick, D. C. (2017). Red, blue, and purple firms: Organizational political ideology and corporate social responsibility. Strategic Management Journal, 38(5), 1018-1040. 
Hall, B. H., Jaffe, A., \& Trajtenberg, M. (2005). Market value and patent citations. RAND Journal of Economics, 16-38.

Harford, J., Mansi, S. A., \& Maxwell, W. F. (2008). Corporate governance and firm cash holdings in the US. Journal of Financial Economics, 87(3), 535-555.

Hopwood, A. G. (1987). The archeology of accounting systems. Accounting, Organizations and Society, 12(3), 207-234.

Hopwood, A. G. (1987). Accounting and gender: An introduction. Accounting, Organizations and Society, 12(1), 65-69.

Human Rights Campaign. (2016). Corporate equality index. Retrieved from https://www.hrc.org/blog/corporations-celebrate-corporate-equality-index-2016-rating

Human Rights Campaign (2015). LGBTQ Equality at the Fortune 500. Retrieved from https://www.hrc.org/resources/lgbt-equality-at-the-fortune-500.

Jackson, S. E., \& Joshi, A. (2004). Diversity in social context: a multi-attribute, multilevel analysis of team diversity and sales performance. Journal of Organizational Behavior, 25(6), 675-702.

Johnson, I., \& Cooper, D. (2015). LGBT diversity: Show me the business case. Retrieved from https://www.outnowconsulting.com/market-reports/lgbt-diversity-show-me-thebusiness-case-report.aspx.

Johnston, D., \& Malina, M. A. (2008). Managing sexual orientation diversity: The impact on firm value. Group \& Organization Management, 33(5), 602-625.

Kelly, G. M. (2016). Transitioning into Modern Society: Why the Law Is Not Keeping up with Gender Identity. JL \& Com., 35, 101.

King, E. B., \& Cortina, J. M. (2010). The social and economic imperative of lesbian, gay, bisexual, and transgendered supportive organizational policies. Industrial and Organizational Psychology, 3(1), 69-78.

Lardaro, L. (1993). Applied Econometrics. New York: Harper Collins

Lennox, C. S., Francis, J. R., \& Wang, Z. (2011). Selection models in accounting research. The Accounting Review, 87(2), 589-616.

Liddle, B. J., Luzzo, D. A., Hauenstein, A. L., \& Schuck, K. (2004). Construction and validation of the lesbian, gay, bisexual, and transgendered climate inventory. Journal of Career Assessment, 12(1), 33-50.

Liu, Y., Wei, Z., \& Xie, F. (2014). Do women directors improve firm performance in China? Journal of Corporate Finance, 28, 169-184.

Lloren, A., \& Parini, L. (2017). How LGBT-supportive workplace policies shape the experience of lesbian, gay men, and bisexual employees. Sexuality Research and Social Policy, 14(3), 289-299.

Miller, T., \& del Carmen Triana, M. (2009). Demographic diversity in the boardroom: Mediators of the board diversity-firm performance relationship. Journal of Management studies, 46(5), 755-786.

Mouritsen, J., \& Kreiner, K. (2016). Accounting, decisions and promises. Accounting, Organizations and Society, 49, 21-31.

Omankhanlen, A. E., \& Ogaga-Oghene, J. (2011). The impact of workforce diversity on organizational effectiveness: a study of a Nigerian bank. Annals of the University of Petroşani, Economics, 11(3), 93-110.

Østergaard, C. R., Timmermans, B., \& Kristinsson, K. (2011). Does a different view create something new? The effect of employee diversity on innovation. Research Policy, 40(3), 500-509.

Ozeren, E. (2014). Sexual orientation discrimination in the workplace: A systematic review of literature. Procedia-Social and Behavioral Sciences, 109, 1203-1215. 
Ozturk, M. B., \& Tatli, A. (2016). Gender identity inclusion in the workplace: Broadening diversity management research and practice through the case of transgender employees in the UK. The International Journal of Human Resource Management, 27(8), 781-802.

Palincsar, A. S. (1998). Social constructivist perspectives on teaching and learning. Annual Review of Psychology, 49(1), 345-375.

Pathan, S. (2009). Strong boards, CEO power and bank risk-taking. Journal of Banking \& Finance, 33(7), 1340-1350.

Petersen, M. A. (2009). Estimating standard errors in finance panel data sets: Comparing approaches. Review of Financial Studies, 22(1), 435-480.

Petersmann, E. U. (2008). Human rights, international economic law and 'constitutional justice'. European Journal of International Law, 19(4), 769-798.

Pichler, S., Blazovich, J. L., Cook, K. A., Huston, J. M., \& Strawser, W. R. (2018). Do LGBT-supportive corporate policies enhance firm performance? Human Resource Management, 57(1), 263-278.

Pichler, S., Ruggs, E., \& Trau, R. (2017). Worker outcomes of LGBT-supportive policies: A cross-level model. Equality, Diversity and Inclusion: An International Journal, 36(1), 17-32.

Porter, M. E., \& Stern, S. (2001). Innovation: Location matters. MIT Sloan Management Review, 42(4), 28.

Priola, V., Lasio, D., De Simone, S., \& Serri, F. (2014). The sound of silence. Lesbian, gay, bisexual and transgender discrimination in 'inclusive organizations'. British Journal of Management, 25(3), 488-502.

Ragins, B. R. (2008). Disclosure disconnects: Antecedents and consequences of disclosing invisible stigmas across life domains. Academy of Management Review, 33(1), 194-215.

Ragins, B. R., \& Cornwell, J. M. (2001). Pink triangles: Antecedents and consequences of perceived workplace discrimination against gay and lesbian employees. Journal of Applied Psychology, 86(6), 1244.

Rawls, J. (1971). A theory of justice. Cambridge, MA: Harvard University Press.

Rhodes, C. (2017). Ethical Praxis and the Business Case for LGBT Diversity: Political Insights from Judith Butler and Emmanuel Levinas. Gender, Work \& Organization, 24(5), 533-546.

Roberts, J. (2009). No one is perfect: The limits of transparency and an ethic for 'intelligent' accountability. Accounting, Organizations and Society, 34(8), 957-970.

Roodman, D. (2006). How to do Xtabond2: An Introduction to Difference and System GMM in Stata (Center for Global Development Working Paper No. 103). Retrieved from https://ssrn.com/abstract=982943

Rosenbaum, P. R., \& Rubin, D. B. (1983). The central role of the propensity score in observational studies for causal effects. Biometrika, 41-55.

Rutherford, M. A., \& Buchholtz, A. K. (2007). Investigating the relationship between board characteristics and board information. Corporate Governance: An International Review, 15(4), 576-584.

Schneider, B., Ehrhart, M. G., \& Macey, W. H. (2013). Organizational climate and culture. Annual Review of Psychology, 64, 361-388.

Sears, B., \& Mallory, C. (2011). Economic motives for adopting LGBT-related workplace policies. Retrived from: http://williamsinstitute.law.ucla.edu/wpcontent/uploads/Mallory-Sears-Corp-Statements-Oct2011.pdf.

Sen, A. (1995). Gender inequality and theories of justice. Women, culture and development: A study of human capabilities, 259-273.

Shan, L., Fu, S., \& Zheng, L. (2017). Corporate sexual equality and firm performance. Strategic Management Journal, 38(9), 1812-1826. 
Snider, J., Hill, R. P., \& Martin, D. (2003). Corporate social responsibility in the 21st century: A view from the world's most successful firms. Journal of Business Ethics, 48(2), 175187.

Stambaugh, C. T., \& Carpenter, F. W. (1992). The roles of accounting and accountants in executive information systems. Accounting Horizons, 6(3), 52.

Theodorakopoulos, N., \& Budhwar, P. (2015). Guest editors' introduction: Diversity and inclusion in different work settings: Emerging patterns, challenges, and research agenda. Human Resource Management, 54(2), 177-197.

Tilscik, A. (2011). Pride and prejudice: Employment discrimination against openly gay men in the United States. Journal of Sociology, 117, 586-626.

Turnbull, H., Greenwood, R., Tworoger, L., \& Golden, C. (2011). The inclusion skills measurement profile: Validating an assessment for identification of skill deficiencies in diversity and inclusion. Journal of Organizational Culture, Communications and Conflict, 15(1), 11.

United Nations. (2016). Combatting discrimination based on sexual orientation and gender $\begin{array}{lllll}\text { identity. } & \text { Retrieved } & \text { May } & 2018 \text { from }\end{array}$ www.ohchr.org/EN/Issues/Discrimination/Pages/LGBT.aspx

Van Dijk, H., van Engen, M., \& Paauwe, J. (2012). Reframing the business case for diversity: A values and virtues perspective. Journal of Business Ethics, 111(1), 73-84.

Wang, P., \& Schwarz, J. L. (2010). Stock price reactions to GLBT non-discrimination policies. Human Resource Management, 49(2), 195-216.

Weber, M. (1978). Economy and society: An outline of interpretive sociology (vol. 1). University of California Press.

Webster, J. R., Adams, G. A., Maranto, C. L., Sawyer, K., \& Thoroughgood, C. (2018). Workplace contextual supports for LGBT employees: A review, meta-analysis, and agenda for future research. Human Resource Management, 57(1), 193-210.

Wintoki, M. B., Linck, J. S., \& Netter, J. M. (2012). Endogeneity and the dynamics of internal corporate governance. Journal of Financial Economics, 105(3), 581-606.

Wooldridge, J. M. (2002). Inverse probability weighted M-estimators for sample selection, attrition, and stratification. Portuguese Economic Journal, 1(2), 117-139. 